\title{
Prevalence of national treatment algorithm defined smear positive pulmonary tuberculosis in HIV positive patients in Brazzaville, Republic of Congo
}

Laure Stella Ghoma Linguissi ${ }^{1,2}$, Pembe Issamou Mayengue ${ }^{1,2}$, Anissa Sidibé ${ }^{1,2}$, Jeannhey C Vouvoungui ${ }^{1,2}$, Mitawa Missontsa ${ }^{1,2}$, Igor Kevin Madzou-Laboum4, Gaston Bango Essassa ${ }^{4}$, Sunny Oyakhirome ${ }^{1}$, Matthias Frank ${ }^{3,6}$, Veronique Penlap ${ }^{5}$ and Francine Ntoumi ${ }^{1,2,3^{*}}$

\begin{abstract}
Background: In the Republic in Congo, the national algorithm for the diagnosis of pulmonary tuberculosis (TB) relies on Ziehl-Neelsen (ZN) sputum smear microscopy, chest X-ray radiography (CXR) and clinical symptoms. Microscopy positive pulmonary TB (MPT+) is defined as symptoms of TB and a positive ZN smear. Microscopy negative pulmonary TB (MPT-) is defined as symptoms of TB, a negative ZN smear but CXR changes consistent with TB. The present cross-sectional study was designed to determine the prevalence of positive and negative MPT individuals among HIV positive and HIV negative individuals presenting to an ambulatory TB treatment center (CTA) in Brazzaville.

Methods: All study participants underwent a physical examination, chest radiography and three ZN sputum smear examinations and HIV testing. Viral load and CD4 counts were determined for HIV positive individuals.

Results: 775 individuals presented with symptoms of TB. 425 individuals accepted the voluntary HIV test. 133 (31.3\%) were HIV positive (HIV+) and 292 (68.7\%) were HIV negative (HIV-). Of the 292 HIV- individuals 167 (57\%) were classified as positive MPT and 125 (43\%) as negative MPT. Of the 133 HIV positive individuals 39 (29\%) were classified as MPT + and 94 (71\%) as MPT-.

Conclusion: Our study shows that the prevalence of positive MPT individuals is lower among HIV positive individuals compared to HIV negative individuals in agreement to reports from other countries. The data suggest that a substantial number of HIV positive pulmonary TB cases are not detected by the national algorithm and highlight the need for new diagnostic tests in this population.
\end{abstract}

Keywords: Tuberculosis, Microscopy, Pulmonary TB, HIV infection, Republic of Congo

\section{Background}

There are approximately 34 million people currently living with HIV, one-third of these is estimated to also be infected with tuberculosis (TB) [1-3]. Although antiretrovirals (ARV) can reduce the risk of death in HIV infected individuals, an untreated TB patient starting this

\footnotetext{
* Correspondence: fntoumi@fcrm-congo.com

${ }^{1}$ Fondation Congolaise pour la Recherche Médicale, Brazzaville, Republic of Congo

${ }^{2}$ Faculté des Sciences de la Santé, Université Marien Ngouabi, Brazzaville PB 2672, Republic of Congo

Full list of author information is available at the end of the article
}

therapy might be exposed to immune-reconstitution inflammatory syndrome (IRIS) which is associated with increased morbidity and potential mortality [4].

In sub-Saharan Africa, TB is often the first manifestation of HIV infection, and it is the leading cause of death among HIV infected patients [5-7]. The countries of the world with the highest HIV prevalence rates are also those with high rates of TB [8], these countries include: Swaziland, Botswana, Lesotho, and South Africa $[1,9]$. The highest number of TB/HIV co-infection has been reported in southern Africa, where more than $60 \%$ of TB patients are HIV positive $[5,6,10]$. The burden of

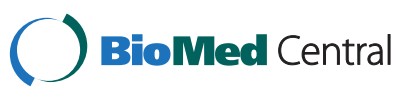


TB and TB-HIV co-infection is no less alarming in the Republic of Congo. According to the World Health Organization (WHO), in 2011, the incidence of TB in Republic of Congo was 473 per 100,000 population (including TB/HIV co-infections) and $31 \%$ of TB patients were HIV positive [11].

The diagnosis of HIV-associated TB is often challenging and nucleic acid amplification tests, including the GeneXpert MTB/RIF assay and urinary LAM assays are known to improve the diagnosis of both smear-negative and extrapulmonary TB in HIV positive individuals [12].

TB diagnosis worldwide currently heavily relies on sputum smear microscopy to detect acid-fast bacilli (AFB), as it is rapid, inexpensive, and highly specific for identifying active pulmonary tuberculosis (PTB) [13,14]. This technique is known to identify the most cases with excellent specificity, but has an approximate sensitivity of $35 \%$ to $70 \%$ [15-18]. Indeed, a particular challenge for clinicians is the rising incidence of HIV related TB, often associated with an increase in smear negative microscopy cases [19-22] Unfortunately, the most sensitive techniques available such as mycobacterial culture and nucleic acid amplification techniques, are expensive, resource intensive and thus not routinely available in many African countries [23-27]. Current culture-based methods takes more than two weeks [28] and there is a need for faster diagnosis of TB in HIV- and HIV + patients as well as delays in diagnosis and treatment are associated with high mortality risk [29-32].

In the Republic of Congo, the current national guidelines for TB diagnosis relies on sputum smear microscopy, X-ray radiography and clinical symptoms to confirm TB cases (Figure 1). The present study is designed as a diagnostic cross sectional study of HIV + and HIV - patients suspected of having pulmonary TB. We aimed to demonstrate the utility of the national diagnosis algorithm in confirming pulmonary TB in HIV + and HIV -individuals. In addition we assessed virologic and immunologic parameters in the HIV positive individuals. More specifically, we seek to evaluate the need to implement new diagnostic tools to increase the detection rate of $\mathrm{TB}$ in $\mathrm{HIV+/sputum} \mathrm{smear-negative} \mathrm{cases.}$

\section{Methods}

\section{Selection of patients}

The study participants were recruited at the antituberculosis center (CAT) of Brazzaville during the study period from February to June 2011. All consecutive TB suspects regardless of HIV status were eligible for the study. Informed consent was obtained from all study participants or their guardians. Ethical authorization was obtained from the Comité d'éthique Institutionnel de la Recherche en Santé (CERSSA) (No. 00000067/DGRST/ CERSSA).

\section{Specimen collection}

Demographic data (age, place of residence) and clinical data were recorded for all participants during a medical interview and a physical examination by a clinician. Chest radiography and sputum collection was performed according to the national diagnostic algorithm. Participants provided three sputum specimens over the course of 2 days. The first specimen was collected when the patient attended the CAT for the first time. A container was given to the participant for collecting an early morning sample at home the next day, and a third was collected again at the center when the patient brought back the early morning specimen. The samples were tested with the direct Ziehl-Neelsen light microscopy method following standard instructions on proper sputum submission. Sputum microscopy was performed at the onsite laboratory, with density of acid fast bacilli graded as 1,2 or $3+$.

\section{HIV testing}

Blood samples were tested using two rapid tests, Determine HIV 1/2 test (Alere GmbH, Koln, Germany) and ImmunoComb II HIV 1 \& 2 BiSpot (Orgenics, Yavne, Israel). In case of discordance between these two tests, the enzyme-linked immunosorbent assay (ELISA, Vironostika HIV-1 Plus O Microelisa System, UK) was performed by the reference lab which is the Laboratoire National de Santé Publique.

\section{CD4+/CD8+ cells counts}

Approximately $5 \mathrm{ml}$ of blood was collected in an EDTA tube for counting $\mathrm{T}$ cells. The blood samples were processed immediately within 2 hours of collection, for determination of the absolute counts of CD4+, CD8+ cells by activated cell sorting (FACS) count (Partec $\mathrm{GmbH}$, Munster, Germany), following manufacturer's instructions.

\section{Quantification of plasma viral load}

Quantification of plasma viral load of HIV-1 was done using Biocentric ${ }^{\mathrm{TM}} \mathrm{kit}$, on a platform of Roche LightCycler ${ }^{\odot}$ 480 using the technique of real-time PCR. A volume of $10 \mathrm{ml}$ obtained after RNA extraction from plasma was used for analysis. The detection limit was 1,500 viral RNA copies / $\mathrm{ml}$ (2.3 log copies / ml). The determination of viral load was performed at the Laboratory of Molecular Biology at the Faculty of Health Sciences/University Marien Ngouabi, Brazzaville.

\section{National diagnosis algorithm (Figure 1)}

At the first consultation, all patients suspected of TB were clinically assessed by a trained health professional. The assessment includes screening for clinical signs and symptoms such as current cough (if self-reported cough was $>2$ weeks), fever, night sweats and weight loss. Sputum 


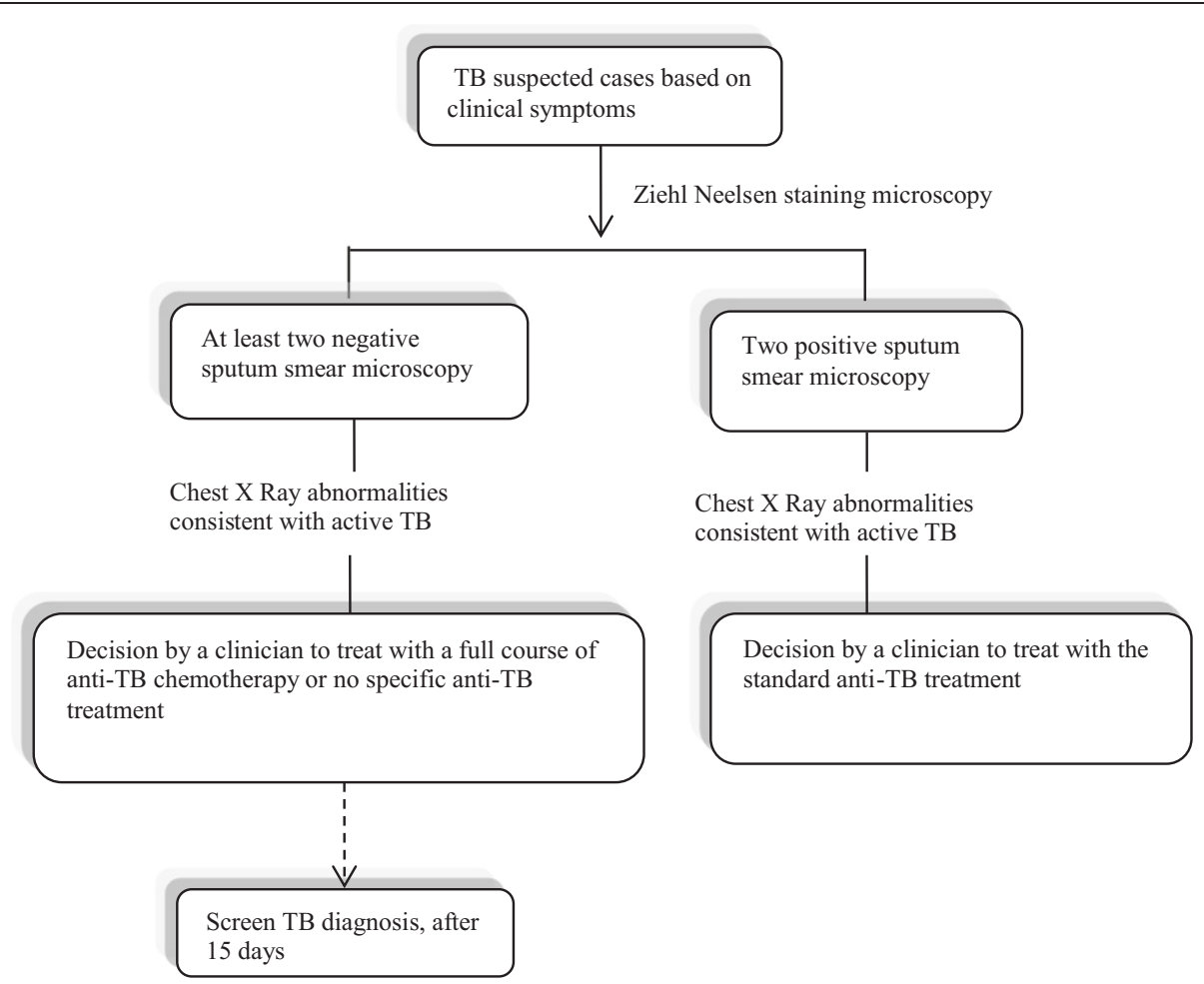

Figure 1 National algorithm for the diagnosis of pulmonary TB.

samples were collected and examined using Ziehl-Neelsen staining microscopy. A chest X-ray was performed and HIV testing was offered to all individuals.

\section{Case definitions}

Pulmonary TB (PTB) positive microscopy: Patients with at least 2 positive sputum samples were classified as positive for pulmonary TB. These PTB positive patients were given the standard anti-TB treatment according to National guidelines.

Pulmonary TB negative microscopy: Patients with at least 2 sputum samples negative for AFB and with symptoms of $\mathrm{TB}$, a negative $\mathrm{ZN}$ smear but CXR changes consistent with TB were classified as negative for pulmonary TB. These PTB negative patients were treated with a full course of anti-TB chemotherapy if 15 days later the screening is positive.

Patients without pulmonary TB: Individuals with negative sputum samples for AFB and no X-ray changes suggestive of TB.

\section{Statistical analysis}

The demographic, clinical and laboratory results were entered into a database and analyzed using SPSS version 16 (SPSS Inc, Chicago, IL, USA). The mean and standard deviation of the age, CD4 and CD8 T cells and viral load were calculated using student's t-test for comparison.
Logistic regression was used to evaluate the effect of age, gender and clinical parameters on HIV infection. KruskalWallis test was used to compare the proportion of HIV infected patients with different levels of CD4+, CD8+ T cells and viral load between AFB positive and negative microscopy. Differences were considered statistically significant when the $\mathrm{p}$ value was $\leq 0.05$.

\section{Results}

Characteristic of patients who consented to the HIV test

From February to June 2011, 775 patients attending the consultation service at the TB center of Brazzaville (CAT) were deemed suspected TB cases based on clinical examination (Figure 2). Of these, 425 (54.8\%) underwent HIV testing at the time of TB diagnosis specimen collection. Among these, 133 (31.3\%) were HIV + and 292 were HIV-.

As presented on Table 1, the mean age of all participants was 34.9 years \pm 13.01 and most of the patients were older than 25 years. Gender, signs of TB, axillary temperature did not significantly differ according to HIV status.

Of the 292 HIV- individuals, 167 (57\%) were classified as PTM positive and 125 (43\%) as PTM negative. Of the $133 \mathrm{HIV}+$ individuals 39 (29.3\%) were classified as PTM positive and $94(70.7 \%)$ as PTM negative (Table 2 and Figure 2). Thirty-six (92.3\%) and thirty-five (37.2\%) AFB 


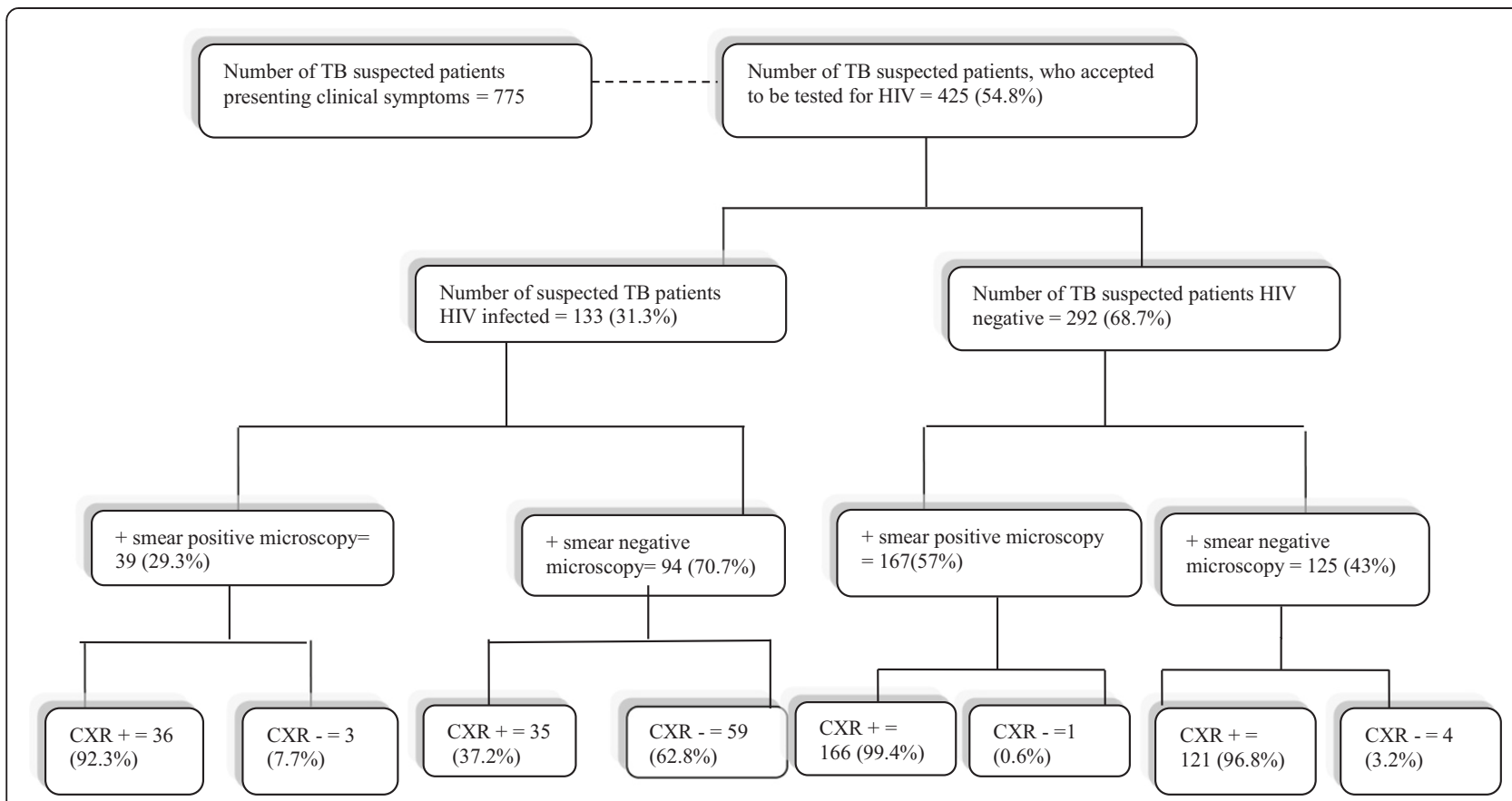

Figure 2 Sputum smear microscopy, HIV test and chest X-Ray results for the study participants. + means Patients with smear positive or smear negative microscopy CXR means Chest X-ray.

positive and negative patients respectively, were positive for X-ray (Figure 2) $(<0.001)$.

\section{CD4+/CD8+ T cells, viral load and sputum microscopy examination in HIV patients}

Concerning the 133 HIV patients, CD4+ T cells counts have been reported according to the results of sputum microscopy examination in Table 2. Overall mean baseline CD4+ and CD8+ T cell count was 289.4 and 850.9 cells $/ \mathrm{ml}$ respectively (Table 2 ). HIV + patients with positive AFB had higher CD4+ counts $(385.4 \pm 278.1$ cells $/ \mathrm{ml}$ ) when compared to those with a negative AFB $(239.6 \pm 274.9$ cells $/ \mathrm{ml})(\mathrm{p}<0.029)$. Patients with CD4 cell counts below 350 cells $/ \mathrm{mm} 3$ were significantly higher among negative AFB patients $(\mathrm{p}<0.007)$. The mean CD4/ CD8 ratio was significantly higher in positive smear pulmonary tuberculosis than negative smear $(0.59$ versus 0.25 , $\mathrm{P}<0.003)$.

The mean viral load was similar in AFB positive and AFB negative groups and no significant difference between those with positive and negative AFB (Table 3) was found.

\section{Discussion}

The burden of TB around the world remains alarming. Microscopy examination of sputum samples is recommended by the WHO as an essential step for patients suspected of pulmonary TB. Unfortunately, smear microscopy has been reported to have low sensitivity [33].
In particular, this technique has limited performance in immune-compromised individuals [34]. A number of studies report that pulmonary TB diagnosis can be achieved through the combination of clinical symptoms, CXRexaminations and smear microscopy [35-37].

As in many countries with limited resources where TB is endemic, the algorithm endorsed by the Congolese national TB control program emphasizes the use of these modalities. In our study, we found that this algorithm identifies less cases of PTB microscopy positive and PTB microscopy negative in HIV + individuals compared to HIV - individuals. It is important to keep in mind that mycobacterial culture or nucleic acid amplification tests are not available in our setting. This is a common limitation encountered in African countries. The true prevalence of pulmonary tuberculosis in our setting is thus not determined.

Our study showed that the rate of $\mathrm{ZN}$ smear positivity is higher in HIV - than in HIV + individuals. Given the well-known increased risk for pulmonary tuberculosis in HIV + individuals the data suggest that a number of $\mathrm{HIV}+$ individuals with pulmonary TB were not detected by $\mathrm{ZN}$ based microscopy $[3,6,9]$. Moreover the lower prevalence of CXR abnormalties in HIV + individuals also suggests that this diagnostic modality may be less sensitive in the HIV + population. Despite the limitation in methodology the present data thus suggest that the national diagnostic treatment algorithm may miss a substantial number of HIV + individuals with pulmonary 
Table 1 Characteristics of patients (who accepted to do the HIV test) enrolled at the TB Center in Brazzaville

\begin{tabular}{|c|c|c|c|c|c|}
\hline & All & HIV positive & HIV negative & Crude OR(95\%Cl) & P-value \\
\hline Number of patients & $425(54.8)$ & 133(31.3) & 292 & - & - \\
\hline Age (years)Mean $\pm S D$ & $34.9 \pm 1$ & $38.37 \pm 9$ & $33.40 \pm 1$ & - & 0.000 \\
\hline \multicolumn{6}{|l|}{ Age group } \\
\hline 14-24ans & $98(23.7)$ & $9(9.2)$ & $89(90.8)$ & Baseline & \\
\hline 25-34ans & 123(29.7) & $33(26.8)$ & $90(73.2)$ & $3.6(1.64-8.01)$ & 0.001 \\
\hline$\geq 35$ ans & 193(46.6) & $84(43.5)$ & $109(56.5)$ & 7.6(3.63-16.00) & $<0.001$ \\
\hline Missing & 11 & & & & \\
\hline \multicolumn{6}{|l|}{ Gender } \\
\hline Female & $177(42.3)$ & $71(40.1)$ & 106(59.9) & & \\
\hline Male & $241(57.7)$ & $55(22.8)$ & 186(77.2) & $0.4(0.29-0.67)$ & $<0.001$ \\
\hline Missing & 7 & & & & \\
\hline \multicolumn{6}{|l|}{ Signs of TB } \\
\hline No & $99(23.9)$ & $34(34.3)$ & $65(65.7)$ & & \\
\hline Yes & 319(76.3) & $92(28.8)$ & $227(71.2)$ & $0.7(0.48-1.25)$ & 0.298 \\
\hline Missing & 7 & & & & \\
\hline \multicolumn{6}{|l|}{ Cough } \\
\hline No & $0(0)$ & 0 & 0 & & \\
\hline Yes & $418(100)$ & $126(30.1)$ & 292(69.9) & - & - \\
\hline Missing & 7 & & & & \\
\hline \multicolumn{6}{|l|}{ Pale skin } \\
\hline No & 355(85.5) & $101(28.5)$ & $254(71.5)$ & & \\
\hline Yes & $60(14.5)$ & $25(41.7)$ & $35(58.3)$ & $1.8(1.02-3.15)$ & 0.041 \\
\hline Missing & 10 & & & & \\
\hline \multicolumn{6}{|c|}{ Axillary temperature $>37.5^{\circ} \mathrm{C}$} \\
\hline No & $37(8.9)$ & $11(29.7)$ & 26(70.3) & & \\
\hline Yes & 379(91.1) & 114(30.1) & 265(69.9) & $1.02(0.48-2.13)$ & 0.965 \\
\hline Missing & 9 & & & & \\
\hline \multicolumn{6}{|l|}{ Asthenia } \\
\hline No & $38(9.3)$ & $8(20.5)$ & $31(79.5)$ & & \\
\hline Yes & 378(90.6) & 117(30.8) & $261(69.2)$ & $1.7(0.78-3.89)$ & 0.180 \\
\hline Missing & 8 & & & & \\
\hline \multicolumn{6}{|l|}{ Anorexia } \\
\hline No & $80(19.1)$ & $17(21.2)$ & $63(78.8)$ & & \\
\hline Yes & 338(80.9) & 109(32.2) & $229(67.8)$ & $1.7(0.98-3.16)$ & 0.056 \\
\hline Missing & 7 & & & & \\
\hline \multicolumn{6}{|l|}{ Weight loss } \\
\hline No & 13(3.12) & 2(15.4) & $11(84.6)$ & & \\
\hline Yes & 404(96.9) & 124(30.7) & $280(69.3)$ & $2.4(0.53-11.15)$ & 0.251 \\
\hline Missing & 8 & & & & \\
\hline \multicolumn{6}{|c|}{ Received TB treatment, after diagnosis } \\
\hline No & $61(14.6)$ & $54(88.5)$ & $7(11.5)$ & & \\
\hline Yes & $357(85.4)$ & $72(20.2)$ & 285(79.8) & $0.03(0.01-0.07)$ & $<0.001$ \\
\hline Missing & 7 & & & & \\
\hline
\end{tabular}


Table 2 CD4+ and CD8+ T cells counts in HIV Congolese patients with positive or negative sputum detected by microscopy using Ziehl-Neelsen staining

\begin{tabular}{|c|c|c|c|c|}
\hline & All & Positive microscopy & Negative microscopy & P-value* \\
\hline Number of HIV-1 patients & $133(31.3 \%)$ & $39(29,3)$ & 94(70.7) & $<0.001-$ \\
\hline \multicolumn{5}{|l|}{ Immunological category (CDC) } \\
\hline CD4+ T-cell count (cells/mm3, mean \pm SD) & $289.4 \pm 282.9$ & $385.4 \pm 278.1$ & $239.6 \pm 274.9$ & 0.029 \\
\hline Absolute CD4+ T-cell counts & $53(67.1)$ & $12(44.4)$ & $41(78.8)$ & \\
\hline$<350 / \mathrm{mm} 3$ & $11(13.9)$ & $7(26)$ & $4(7.7)$ & 0.007 \\
\hline $350-500 / \mathrm{mm} 3$ & 15(19.0) & $8(29.6)$ & $8(13.5)$ & \\
\hline$>500 / \mathrm{mm} 3$ & 54 & & & \\
\hline \multicolumn{5}{|l|}{ Missing } \\
\hline CD8+ T-cell counts (cells/mm3, mean \pm SD) & $850.9 \pm 547.4$ & $647.3 \pm 555.2$ & $956.6 \pm 517.5$ & 0.016 \\
\hline Absolute CD8+ T-cell counts & 18(22.7) & $4(14.8)$ & 14(26.9) & \\
\hline$<400 / \mathrm{mm} 3$ & 16(20.3) & $3(11.1)$ & $13(25)$ & 0.001 \\
\hline 400-799/mm3 & $30(38)$ & $8(29.6)$ & $22(42.3)$ & \\
\hline $800-1200 / \mathrm{mm} 3$ & 15(19) & $12(44.5)$ & $3(5.8)$ & \\
\hline$>1200 / \mathrm{mm} 3$ & 54 & & & \\
\hline \multicolumn{5}{|l|}{ Missing } \\
\hline $\mathrm{CD} 4 / \mathrm{CD} 8$ ratio $($ mean $\pm \mathrm{SD})$ & $0.34 \pm 0.51$ & $0.59 \pm 0.5$ & $0.25 \pm 0.5$ & 0.003 \\
\hline Missing & 54 & & & \\
\hline
\end{tabular}

tuberculosis. However, it is also important to note that patients who are smear-negative in our study, may not have TB. Against this background, we may speculate that many patients could be over-treated for TB.

In our study, the mean CD4/CD8 ratio was lower than 1 , this indicates an increase of PTB among HIV patients, especially for negative smeargroup. Inability to properly diagnose pulmonary TB in the HIV infected population is hazardous to this immnuno-compromised population due to the well-known increased severity of pulmonary tuberculosis in TB-HIV co-infection. In addition there is a risk of immune-reconstitution inflammatory syndrome (IRIS) in patients on antiretroviral therapy with undiagnosed and those with untreated TB [4], this is unmasking TB IRIS. In other words, if TB remains undiagnosed in an HIV positive individual that starts antiretroviral therapy, there is a chance that the patient's immune system may begin to recover but then respond to the TB infection with an overwhelming inflammatory response of patient [38].

Many studies have confirmed the superior effectiveness of culture methods when compared to smear microscopy $[37,39,40]$. To test TB diagnosis algorithms in resource-limited areas, the standard of care (evaluation through clinical symptoms, chest $\mathrm{x}$-rays and smear microscopy) has been compared to confirmation of TB

Table 3 Viral load in HIV Congolese patients with sputum smear positive or negative by microscopy stained using Ziehl-Neelsen staining

\begin{tabular}{|c|c|c|c|c|}
\hline & All & Smear positive microscopy & Smear negative microscopy & P-value \\
\hline Number HIV-1 infected patients & 133 & $39(29,3)$ & $94(70.7)$ & - \\
\hline Mean $\pm S D, \log 10$ copies per $\mathrm{ml}$ & $4.6 \pm 1.6$ & $4.70 \pm 1.7$ & $4.56 \pm 1.6$ & 0.713 \\
\hline Range (min.-max.), log 10 copies / ml & $2.60-7.5$ & $2.60-7.4$ & $2.60-7.5$ & - \\
\hline \multicolumn{5}{|l|}{ Viral load group, copies per ml,\% } \\
\hline$<500$ & $35(36.5)$ & $10(40)$ & $25(35.2)$ & \\
\hline $501-10000$ & 22(22.9) & $6(24)$ & $16(22.5)$ & \\
\hline $10001-250000$ & 10(10.4) & $1(4)$ & $9(12.7)$ & $0.681^{* *}$ \\
\hline$>250000$ & 29(30.2) & $8(32)$ & $21(29.6)$ & \\
\hline Missing & 37 & & & \\
\hline
\end{tabular}

**: Kruskal Wallis Test. 
diagnosis through Mycobacteria Growth Indicator Tube (MGIT) technology which specifically detects and recovers mycobacteria. In a study conducted in Sub-Saharan Africa and South America, the standard of care method was less sensitive in detecting TB than the culture method [39]. In Kenya, [35] a cross sectional study was conducted to ascertain the performance of the 2007 World Health Organization (WHO) algorithm to diagnose PTB in HIV positive individuals. In this study, the use of culture increased significantly the proportion of confirmed TB cases. In 2010, WHO recommended the use of XpertMTB/RIF for HIV positive patients in order to detect Mycobacterium tuberculosis (Mtb) and rifampicin resistance [41]. GeneXpertMTB/RIF were reported to perform better than smear microscopy [42-44]. Recent studies have shown that the urinary LAM test improves the diagnosis of TB in HIV + individuals among those who are severely immunocompromised, however this test performance is high in the very sickest patients $[45,46]$.

The limit of the National algorithm for the diagnosis of TB infection is that no culture lab exists in the country. Moreover, with regard to high risk of HIV people to get TB infection, it would be very useful to test negative sputum samples with the WHO endorsed GeneXpert technology.

\section{Conclusion}

In countries were TB and HIV are endemic, accurate and rapid diagnosis tools should be implemented. It is crucial to have access low-cost tools that are adapted to countries where resources are limited and to support health care providers with adequate training. This study showed that the current national treatment algorithm may adequately detect smear positive pulmonary $\mathrm{TB}$ in HIV- individuals.

In the present study, a consistent number of patients with smear-negative microscopy and negative radiology were found; therefore it is possible that many patients with negative smear pulmonary $\mathrm{TB}$ did not have TB. In order to avoid over-TB treatment, it appears urgent to use locally specific diagnostic methods such as culture or GeneXpert. However, our data also suggest that additional diagnostic modalities are required to diagnose $\mathrm{TB}$ in HIV + individuals, especially those with smearnegative pulmonary tuberculosis.

\section{Competing interests}

We declare that we have no conflict of interest.

\section{Authors' contributions}

PIM, MM, FN, MF, VP: Study design. LSGL, SAS, LKM, BE, SO: recruitment of patients, carried out analyses. JCV, LSGL, SAS, FN: data analysis. LSGL, PIM, FN: Drafted the paper. All authors read and approved the final manuscript.

\section{Acknowledgement}

We thank all the participants to this study. We also thank Drs. Rüsch-Gerdes and Stephan Nieman for their contribution to this work. LSGL, PIM, JV, MM and FKK received support of CANTAM network. Dr S. Oyakhiromen is recipient of EDCTP senior fellowship. We are grateful to Dr Sylvie Kwedi Nolna for the critical reading and editing of the manuscript.

This work has been supported through the Central Africa Network on Tuberculosis, HIV/AIDs and Malaria (CANTAM), which is a network of excellence supported by EDCTP.

\section{Author details}

${ }^{1}$ Fondation Congolaise pour la Recherche Médicale, Brazzaville, Republic of Congo. ${ }^{2}$ Faculté des Sciences de la Santé, Université Marien Ngouabi, Brazzaville PB 2672, Republic of Congo. ${ }^{3}$ Institute for Tropical Medicine, University of Tübingen, Tübingen, Germany. ${ }^{4}$ Centre Antituberculeux de Brazzaville, Programme de Lutte contre la Tuberculose, Brazzaville, Republic of Congo. ${ }^{5}$ University Yaoundé1, Yaoundé, Cameroon. ${ }^{6}$ German Center for Infection Research (DZIF), Braunschweig, Germany.

Received: 8 August 2013 Accepted: 18 August 2014 Published: 28 August 2014

\section{References}

1. Wood R, Lawn SD, Caldwell J, Kaplan R, Middelkoop K, Bekker L-G, Bekker L-G: Burden of New and recurrent tuberculosis in a major south African city stratified by Age and HIV-status. PLoS One 2011, 6(10):e25098. doi:10.1371/ journal.pone.0025098

2. World Health Organization: Global tuberculosis control report. WHO Report 2011, http://www.who.int/tb/publications/global_report/2011/gtbr11_full. pdf. Accessed on 4 July 2013.

3. UNAIDS: Report on the global AIDS epidemic. 2012, http://www.unaids. org/en/media/unaids/contentassets/documents/epidemiology/2012/gr2012/ 20121120_UNAIDS_Global_Report_2012_en.pdf, available the 09/07/2013.

4. Cain KP, McCarthy KD, Heilig CM, Monkongdee P, Tasaneeyapan T, Kanara N, Kimerling ME, Chheng P, Thai S, Sar B, Phanuphak P, Teeratakulpisarn N, Phanuphak N, Nguyen HD, Hoang TQ, Le HT, Varma JK: An algorithm for tuberculosis screening and diagnosis in people with HIV. N Engl J Med 2010, 362(8):707-716.

5. Granich R, Akolo C, Gunneberg C, Getahun H, Williams P, Williams B: Prevention of tuberculosis in people living with HIV. Clin Infect Dis 2010, 50(Supplement 3):S215-S222. doi: 10.1086/651494.

6. WHO, Stop TB Partnership: The Global Plan to Stop TB 2011-2015. Geneva: World Health Organization; 2011.

7. Gray F, Lescure FX, Adle-Biassette H, Polivka M, Gallien S, Pialoux G, Moulignier A: Encephalitis with infiltration by CD8+ lymphocytes in HIV patients receiving combination antiretroviral treatment. Brain Pathol 2013, doi:10.1111/bpa.12038.

8. Godfrey-Faussett P, Ayles H: Can we control tuberculosis in high HIV prevalence settings? Tuberculosis (Edinb) 2003, 83:68-76. PMID: 12758192.

9. Tolu O, Burke R, Tsekela R, Bangani N, Seldon R, Gideon HP, Wood K, Wilkinson KA, Ottenhoff THM, Wilkinson RJ: High prevalence of subclinical tuberculosis in HIV-1-infected persons without advanced immunodeficiency: implications for TB screening. Thorax 2011, 66(8):669-673.

10. Corbett EL, Marston B, Churchyard GJ, De Cock KM: Tuberculosis in sub-Saharan Africa: opportunities, challenges, and change in the era of antiretroviral treatment. Lancet 2006, 367:926-937.

11. World Health Organization: Tuberculosis country profile: Congo. 2013, https://extranet.who.int/sree/Reports?op=Replet\&name=\%2FWHO_HQ_ Reports\%2FG2\%2FPROD\%2FEXT\%2FTBCountryProfile\&ISO2=CG\&LAN= EN\&outtype=html. Accessed on 01 July 2013.

12. Gray JM, Cohn DL: Tuberculosis and HIV coinfection. Semin Respir Crit Care Med 2013, 34(1):32-43. doi:10.1055/s-0032-1333469. Epub 2013 Mar 4.

13. Martínez-Romero A, Ortega-Sánchez JL, González-Yañez MG, HernándezSalgado JR, Ruíz-Baca E, Alba-Romero JJ, Cervantes-Flores M: Comparison of acid-fast bacilli smear and chromatographic immunoassay in patients with active tuberculosis. Afr J Microbiol Res 2012, 6(8):1690-1693.

14. Swai HF, Mugusi FM, Mbwambo JK: Sputum smear negative pulmonary tuberculosis: sensitivity and specificity of diagnostic algorithm. BMC Res Notes 2011, 4:475.

15. Brodie D, Schluger NW: The diagnosis of tuberculosis. Clin Chest Med 2005, 26:247-271.

16. Lawn SD, Brooks SV, Kranzer K, Nicol MP, Whitelaw A, Vogt M, Bekker LG, Wood R: Screening for HIV-associated tuberculosis and rifampicin resistance before antiretroviral therapy using the xpert MTB/RIF 
assay: a prospective study. PLoS Med 2011, 8(7):e1001067. doi:10.1371/journal.pmed.1001067.

17. Nahid P, Kim PS, Evans CA, Alland D, Barer M, Diefenbach J, Ellner J, Hafner R, Hamilton CD, lademarco MF, Ireton G, Kimerling ME, Lienhardt C, MacKenzie WR, Murray M, Perkins MD, Posey JE, Roberts T, Sizemore C, Stevens WS, Via L, Williams SD, Yew WW, Swindells S: Clinical research and development of tuberculosis diagnostics: moving from silos to synergy. J Infect Dis 2012, 205:S159-S168.

18. Mugusi F, Villamor E, Urassa W, Saathoff E, Bosch RJ, Fawzi WW: HIV co-infection, CD4 cell counts and clinical correlates of bacillary density in pulmonary tuberculosis. Int J Tuberc Lung Dis 2006, 10:663-669.

19. Harries AD, Zachariah R, Lawn SD: Providing HIV care for co-infected tuberculosis patients: a perspective from sub-Saharan Africa. Int Tuberc Lung Dis 2009, 13(1):6-16.

20. Padmanesan N, Wood J, Maclntyre CR, Mathai D: Risk factors for tuberculosis. Pulmonary medicine. 2013, 2013: Article ID 828939. http:// www.readcube.com/articles/10.1155/2013/828939?locale=en.

21. Dimairo M, MacPherson $P$, Bandason T, Zezai A, Munyati SS, Butterworth AE, Mungofa S, Rusikaniko S, Fielding K, Mason PR, Corbett EL: The risk and timing of tuberculosis diagnosed in smear-negative TB suspects: a 12 month cohort study in Harare, Zimbabwe. PLoS One 2010, 5(7):e11849. doi:10.1371/journal.pone.0011849.

22. Brouwer $M$, Gudo PS, Simbe CM, Perdigão $P$, Van Leth F: Are routine tuberculosis programme data suitable to report on antiretroviral therapy use of HIV-infected tuberculosis patients? BMC Rese Notes 2013, 6:23. doi:10.1186/1756-0500-6-23.

23. Dowdy DW, Lourenço MC, Cavalcante SC, Saraceni V, King B, Golub JE, Bishai D, Durovni B, Chaisson RE, Dorman SE: Impact and cost-effectiveness of culture for diagnosis of tuberculosis in HIV-infected Brazilian adults. PLoS One 2008, 3(12):e4057. doi:10.1371/journal.pone.0004057.

24. Soumya S, Padmapriyadarsini C, Narendran G: HIV-associated tuberculosis: clinical update. Clin Infect Dis 2010, 50(10):1377-1386. doi:10.1086/652147.

25. Cavanaugh JS, Shah NS, Cain KP, Winston CA: Survival among patients with HIV infection and smear-negative pulmonary tuberculosis - United States, 1993-2006. PLoS One 2012, 7(10):e47855. doi:10.1371/journal. pone.0047855

26. Benova L, Fielding K, Greig J, Nyang'wa B-T, Casas EC, da Fonseca, du Cros P: Association of BMI category change with TB treatment mortality in HIVpositive smear-negative and extrapulmonary TB patients in Myanmar and Zimbabwe. PLoS One 2012, 7(4):e35948. doi:10.1371/journal.pone.0035948.

27. Padmapriyadarsini G, Swaminathan N, Swaminathan S: Diagnosis \& treatment of tuberculosisin HIV co-infected patients. Indian J MedRes 2011, 134:850-865.

28. Foongladda S, Klayut W, Chinli R, Pholwat S, Houpt ER: Use of mycobacteriophage qPCR on MGIT broths for a rapid tuberculosis antibiogram. J Clin Microbiol 2014, 52:1523-1528. doi:10.1128/ JCM.03637-13.

29. Lawn SD, Wood R: Tuberculosis in antiretroviral treatment services in resource-limited settings: addressing the challenges of screening and diagnosis. J Infect Dis 2011, 204(suppl 4):S1159-S1167. doi:10.1093/infdis/jir411.

30. Rossato Silva D, Müller AM, Tarso Roth Dalcin DP: Factors associated with delayed diagnosis of tuberculosis in hospitalized patients in a high TB and HIV burden setting: a cross-sectional study. BMC Infect Dis 2012, 12:57. doi:10.1186/1471-2334-12-57

31. Adeiza MA, Abba AA, Okpapi JU: HIV-associated tuberculosis: a sub-Saharan African perspective. 2014, 1(1):1-14.

32. Alvarez-Uria G, Naik PK, Pakam R, Bachu L, Midde M: Natural history and factors associated with early and delayed mortality in HIV-infected patients treated of tuberculosis under directly observed treatment short-course strategy: a prospective cohort study in India. Interdiscip Perspect Infect Dis 2012, 2012:. Article ID 502012, 9 pages. http://dx.doi.org/ 10.1155/2012/502012.

33. Desikan P: Sputum smear microscopy in tuberculosis: is it still relevant? Indian J Med Res 2013, 137:442-444.

34. Perkins MD: New diagnostic tools for tuberculosis. Int J Tuberc Lung Dis 2000, 12(2):S182-S188.

35. Huerga H, Varaine F, Okwaro E, Bastard M, Ardizzoni E, Sitienei J, Chakaya J, Bonnet M: Performance of the 2007 WHO algorithm to diagnose smearnegative pulmonary tuberculosis in a HIV prevalent setting. PLoS One 2012, 7(12):e51336. doi:10.1371/journal.pone.0051336.
36. Hoffmann CJ, Variava E, Rakgokong M, Masonoke K, van der Watt M, Chaisson RE, Martinson NA: High prevalence of pulmonary tuberculosis but Low sensitivity of symptom screening among HIV-infected pregnant women in South Africa. PLoS One 2013, 8(4):e62211. doi:10.1371/journal. pone.0062211.

37. Davis JL, Worodria W, Kisembo H, Metcalfe JZ, Cattamanchi A, Kawooya M, Kyeyune R, den Boon S, Powell K, Okello R, Yoo S, Huang L: Clinical and radiographic factors Do Not accurately diagnose smear-negative tuberculosis in HIV-infected inpatients in Uganda: a cross-sectional study. PLoS One 2010, 5(3):e9859.

38. Mayer K: Immune reconstitution inflammatory syndrome: a reappraisal. Clin Infect Dis 2009, 48(1):101-107. doi:10.1086/595006.

39. Swindells S, Komarow L, Tripathy S, Cain KP, MacGregor RR, Achkar JM, Gupta A, Veloso VG, Asmelash A, Omoz-Oarhe AE, Gengiah S, Lalloo U, Allen R, Shiboski C, Andersen J, Qasba SS, Katzenstein DK, AIDS Clinical Trials Group 5253 Study Team: Screening for pulmonary tuberculosis in HIV-infected individuals: AIDS clinical trials group protocol A5253. Int J Tuberc Lung Dis 2013, 17(4):532-539. doi:10.5588/ijtld.12.0737.

40. Narendran G, Selvakumar N, Risbud AR, Sheta D, Rajasekaran S, Thomas A, Wares F, Swaminathan S: Evaluation of a diagnostic algorithm for sputum smear-negative pulmonary tuberculosis in HIV-infected adults. J Acquir Immune Defic Syndr 2013, 63(3):331-338. doi:10.1097/QAl.0b013e31829341af.

41. World Health Organization: Tuberculosis diagnostics xpertmtb/Rif test. WHO Endorsement and Recommendations 2010, http://www.who. int/tb/features_archive/factsheet_xpert_may2011update.pdf. Accessed on July 3, 2013

42. O'Grady J, Bates M, Chilukutu L, Mzyece J, Cheelo B, Chilufya M, Mukonda L, Mumba M, Tembo J, Chomba M, Kapata N, Maeurer M, Rachow A, Clowes P, Hoelscher M, Mwaba P, Zumla A: Evaluation of the xpert MTB/RIF assay at a tertiary care referral hospital in a setting where tuberculosis and HIV infection Are highly endemic. Clin Infect Dis 2012, 55(9):1171-1178. doi:10.1093/cid/cis631.

43. Steingart KR, Sohn H, Schiller I, Kloda LA, Boehme CC, Pai M, Dendukuri N: Xpert ${ }^{\oplus}$ MTB/RIF assay for pulmonary tuberculosis and rifampicin resistance in adults. Cochrane Database Syst Rev 2013, (1):. Art. No.: CD009593. doi:10.1002/14651858.CD009593.pub2

44. Carriquiry G, Otero L, González-Lagos E, Zamudio C, Sánchez E, Nabeta P, Campos M, Echevarría J, Seas C, Gotuzzo E: A diagnostic accuracy study of Xpert ${ }^{\oplus}$ MTB/RIF in HIV-positive patients with high clinical suspicion of pulmonary tuberculosis in Lima, Peru. PLoS One 2012, 7(9):e44626. doi:10.1371/journal.pone.0044626.

45. Lawn SD, Kerkhoff AD, Vogt M, Wood R: Diagnostic accuracy of a low-cost, urine antigen, point-of-care screening assay for HIV-associated pulmonary tuberculosis before antiretroviral therapy: a descriptive study. Lancet Infect Dis 2012, 12(3):201-209. doi:10.1016/S1473-3099(11) 70251-1. Epub 2011 Oct 17

46. Lawn SD: Point-of-care detection of lipoarabinomannan (LAM) in urine for diagnosis of HIV-associated tuberculosis: a state of the art review. BMC Infect Dis 2012, 12:103. doi:10.1186/1471-2334-12-103. Review.

\section{doi:10.1186/1756-0500-7-578}

Cite this article as: Linguissi et al.: Prevalence of national treatment algorithm defined smear positive pulmonary tuberculosis in HIV positive patients in Brazzaville, Republic of Congo. BMC Research Notes 2014 7:578.

\section{Submit your next manuscript to BioMed Central and take full advantage of:}

- Convenient online submission

- Thorough peer review

- No space constraints or color figure charges

- Immediate publication on acceptance

- Inclusion in PubMed, CAS, Scopus and Google Scholar

- Research which is freely available for redistribution 